\title{
Listrik mikro hidro berdasarkan Potensi debit andalan sungai batanghari kota jambi
}

\author{
Hendi Matalata \\ ${ }^{1}$ Jurusan Teknik Listrik, Fakultas Teknik, Universitas Batanghari \\ "Corresponding author, e-mail: : dermahadihendi@yahoo.co.id
}

\begin{abstract}
Abstrak
Kota Jambi merupakan daerah yang dibentangi sungai batanghari, kajian mengenai pemanfaatan terhadap enegi listrik terbarukan khususnya tenaga air melalui anak sungai perlu di pertimbangkan untuk perencanan Pembangkit Listrik Tenaga Mikro Hidro (PLTMH). Kondisi air yang dapat dimanfaatkan sebagai sumberdaya (resources) penghasil listrik memiliki kapasitas aliran dan ketinggian tertentu dari sistem saluran airnya. Masalah utama dalam pembangkitan listrik tenaga air adalah ketersediaan debit air sungai sebagai energi penggerak pembangkit. Oleh karenanya dibutuhkan teknik tertentu untuk memprediksi potensi aliran air sungai pada sepanjang waktu atau debit andalan sungai yang dapat digunakan untuk energi pembangkit listrik tenaga mikro hidro, tidak terjadinya hujan dengan waktu yang lama serta kondisi daerah aliran sungai (DAS) yang kritis dapat menyebabkan aliran air sungai menjadi kecil bahkan menjadi kering. Pengukuran debit sungai secara manual pada waktu tertentu hanya dapat merepresentasi volume debit sungai pada saat dilakukan pengukuran. Perubahan yang terjadi akibat terjadinya hujan pada waktu berikutnya, atau penurunan debit sungai karena simpanan air tanah yang mengecil, tidak dapat terpantau dengan baik maka perlu direncanakan debit yang kontiniu untuk kapasitas putaran turbin generator dengan memperhitungkan kapasitas listrik dari generator yang dapat dibangkitkan secara optimal
\end{abstract}

Kata Kunci : pembangkit listrik, mikrohidro, Perencanaan, Sungai

\begin{abstract}
The city of Jambi is an area batanghari river, the study of the utilization of renewable energy, especially hydro power through the tributaries should be considered for the planning of Micro Hydro Power Plant (PLTMH). Water conditions that can be utilized as electricity generating resources have a certain flow capacity and altitude of their drainage system. A major problem in hydroelectric generation is the availability of river water discharge as a propulsion energy. Therefore, certain techniques are needed to predict the potential flow of river water at all times or the river's main discharge that can be used for hydro-electric power generation, no long-term rainfall and critical watershed conditions can cause water flow the stream becomes small and even becomes dry. Manual river flow measurements over time can only represent the volume of river flow at the time of measurement. Changes that occur due to the occurrence of rain at a later time, or decrease in river discharge due to decreased soil water savings, can not be monitored properly it is necessary to plan a continuous discharge for the capacity of generator turbine rotation by calculating the electrical capacity of the generator which can be generated optimally
\end{abstract}

Keywords : power plant, micro hydro, Planning, River

\section{PENDAHULUAN}

Sungai Batanghari merupakan sungai terpanjang yang ada di Pulau Sumatra., sebagian dari sungai ini mengaliri Provinsi Sumatra Barat, namun lebih dari $70 \%$ daerah aliran sungai berada di Provinsi Jambi. Memiliki panjang mencapai 800 kilometer, sungai batanghari hampir mengaliri setiap kabupaten yang ada di Jambi. Setidaknya sungai ini mengalir dan melintasi beberapa kabupaten di Jambi seperti Batanghari, Bungo, Tebo, Muaro Jambi, Tanjung Jabung Timur dan Kota Jambi sebelum bermuara ke Selat Malaka di daerah Muara Sabak.

Dengan semakin menipisnya cadangan energi fosil serta perlindungan terhadap lingkungan upaya untuk mengekplorasi sumber-sumber energi terbarukan mutlak dilakukan, Selain usaha penghematan energi dalam kehidupan sehari hari perlu adanya usaha 
pemanfaatan potensi energi secara optimal yang ada di sekitar kita, salah satunya pemanfaatan energi air (hydropower) yang melimpas melalui bendungan. Pembangkit listrik mikro hidro (PLTMH) merupakan pembangkit listrik yang dibangkitkan dengan menggunakan energi aliran sungai dengan debit aliran sungai (Q) yang kecil. Karena energi penggerak yang kecil maka kapasitas daya listrik yang dihasilkan juga kecil. Berbagai teknik penggerak diterapkan untuk memaksimalkan energi penggerak, diantaranya dengan menggunakan Turbin Francis dengan sudu berbentuk mangkok yang banyak sehingga proses tekanan menjadi lebih besar. Bagian-bagian utama dari PLTMH yaitu: bendung(weir), saluran pengalih (intake), saluran pembawa/Pipa penstok, bak penenang, turbin, generator, dan panel kontrol. Bagianbagian tersebut didesain sesuai kondisi dan kebutuhan pembangkitan energi listrik di lapangan[1]. Ketersediaan debit air sungai merupakan masalah utama dalam pembangkitan listrik tenaga air dimana untuk mendapatkan debit andalan dibutuhkan data klimatologi, data hidrologi dan peta-peta yang resprentatif.

\section{TINJAUAN PUSTAKA}

Pembangkit listrik mikrohidro adalah pembangkit listrik yang menggunakan energi air (aliran air anak sungai) sebagai energi penggerak generator pembangkit listriknya. Kondisi air yang dapat dimanfaatkan sebagai sumberdaya (resources) penghasil listrik memiliki kapasitas aliran dan ketinggian tertentu dari sistem saluran airnya. Pembangkit listrik mikrohidro kapasitas dan ketinggian aliran mengacu pada jumlah volume aliran air persatuan waktu (flow capacity). Beda ketinggian tempat dari titik pengamatan debit aliran sampai ke bangunan PLTMH dikenal dengan istilah head. Mikrohidro juga dikenal sebagai clean resources karena pembangkit listrik ini mengunakan sumber daya yang telah disediakan oleh alam dan ramah lingkungan[2], menunjukkan bahwa persyaratan utama yang harus dipertimbangkan ketika membangun pembangkit listrik tenaga mikro hidro adalah:
1. Curah hujan dan limpasan yang tersedia sepanjang waktu.

2. Memiliki ketinggian jatuh air (head)

3. Saluran air yang akan menjadi energi penggerak turbin

4. Power house sebagai rumah turbin dan peralatan pembangkit listrik lainnya

5. Saluran pembuangan air.

Debit andalan merupakan acuan potensi debit aliran sungai yang akan digunakan untuk menentukan kapasitan daya listrik dari pembangkit listrik tenaga air yang akan dibangun. Debit aliran yang dihasilkan oleh suatu hujan akan menghasilkan hidrograf yang bentuknya beragam. Keragaman bentuk hidrograf dipengaruhi oleh hujan dan karakteristik DAS yang meliputi keadaan penutup lahan, keadaan permukaan tanah, serta karakteristik penggal jaringan sungai. Dengan memantau bentuk hidrograf suatu sungai dari waktu ke waktu, maka secara otomatis kondisi penutup lahan juga dapat teramati, karena hidrograf debit aliran lebih besar dipengaruhi oleh penutup lahan dalam wilayah suatu DAS. Dengan demikian bentuk hidrograf suatu sungai dapat dijadikan indikator perubahan penutup lahan dalam wilayah suatu DAS (Hadi, 2003).

Debit diperoleh dengan menggunakan rumus

$$
Q=\mathrm{v} . \mathrm{A}
$$

dimana :

$Q=$ debit $\left(\mathrm{m}^{3} / \mathrm{det}\right)$,

$\mathrm{v}=$ kecepatan aliran

(m)

$\mathrm{A}=$ luas penampang basah

(m).

Hubungan keeratan antara debit air dan tinggi muka air dianalisis menggunakan metode logaritma (Linsley dkk (1985).

$$
\mathrm{Q}=\mathrm{a}(\mathrm{h})^{\mathrm{b}}
$$

diamana :

$\mathrm{Q}=$ Debit air sungai $\left(\mathrm{m}^{3} / \mathrm{detik}\right)$

$\mathrm{h}=$ Tinggi muka air $(\mathrm{m})$

$\mathrm{a}$ dan $\mathrm{b}=$ Nilai kontanta 
Potensi debit aliran sungai untuk sumberdaya listrik dianalisis berdasarkan persamaan (Arismunandar dan Kuwahara,2000):

$$
P=9,8 \text {. H . Q . ү́E(Kilo watt) }
$$

Dimana:

$\mathrm{P}=$ tenaga yang dikeluarkan secara

teoritis (Kilo watt)

$\mathrm{H}=$ tinggi jatuh air efektif $(\mathrm{m})$

$\mathrm{Q}=$ debit aliran sungai $\left(\mathrm{m}^{3} \square \mathrm{s}\right)$

$\eta \mathrm{E}=$ efisiensi pembangkit

\section{METODE PENELITIAN}

Metode penelitian yang digunakan adalah metode observasi dan pengukuran lapangan. Metode observasi digunakan untuk pengukuran Tinggi Muka Air (TMA) sungai sebagai potensi tertinggi untuk menghasilkan Debit air sungai batanghari. areal lokasi penelitiaan ditunjukan pada gambar 1. taman tanggo rajo - sijinjang kota jambi

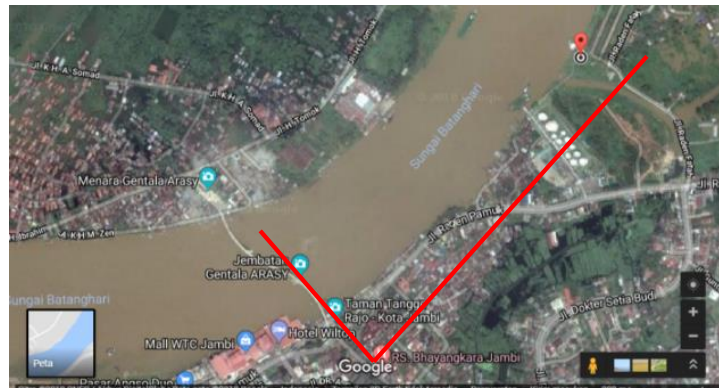

Gambar 1. taman tanggo rajo - sijinjang kota jambi sumber : google map

pada gambar 1. memperlihatkan luasan areal penelitian untuk mendapatkan TMA dan debit air, dimana pengukuran dilakukan dari tanggo rajo (hulu sungai) sampai sijinjang jambi timur (hilir sungai) dengan jarak sungai $\pm 1000 \mathrm{~m}$, dimana sijinjang (hilir sungai) terdapat anak sungai yang direncanakan sebagai areal tempat pembangkit listrik tenaga air, sedangkan lebar sungai didapat dari titik pengukuran tanggo rajo sampai seberang yaitu sebesar $\pm 450 \mathrm{~m}$, luasan sungai diasumsikan berbntuk persegi panjang sehingga besar luasan sungai $400.000 \mathrm{~m}^{2}$.

Ketinggian jatuh air (head) merupakan penjumlahan nilai ketinggian titik pengamatan debit dan nilai ketinggian tempat bagunan pembangkit listrik dan tinggi maksimum sungai setelah dibendung. Campbell (2010), menggambarkan penentuaan Head berdasarkan proses bendungan sungai dan penyaluran air melalui pipa penstock seperti Gambar 2 . Penentuan Head Pembangkit Listrik Mikro Hidro[4].

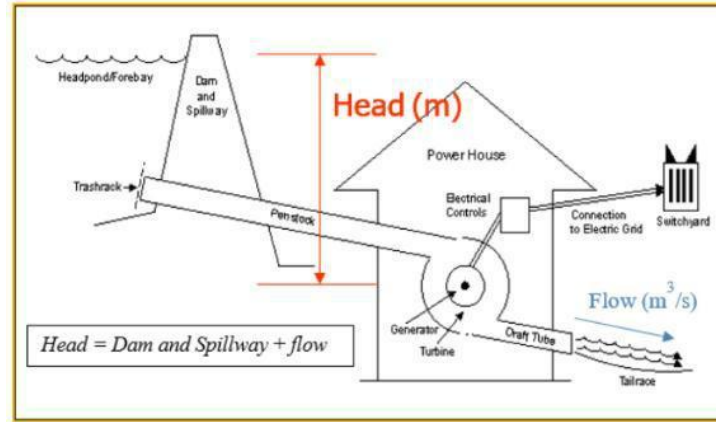

Gambar 2, Penentuan Head Pembangkit Listrik Mikro Hidro (Campbell, 2010).

Dengan asumsi jarak tertentu air sungai yang telah dibendung dialirkan melalui pipa pesat (penstock) menuju rumah pembangkit (power house). Head diperoleh berdasarkan nilai ketinggian air sungai dan dan tempat bangunan turbin generator.

terdapat beberapa jenis turbin generator dalam suatu produksi industri dimana perancangan masing-masing mempunyai spesifikasi yang berbeda, spesifikasi turbin generator pada penelitian ini mempunyai parameter sebagai berikut:

jenis : : Air Turbin dan Generator Set

Model : ZM-3

Output $: 0,6 \mathrm{KW}-100 \mathrm{KW}$

head $: 3-40 \mathrm{~m}$

Debit $\quad: 0,05 \mathrm{~m}^{3} / \mathrm{s}-2,0 \mathrm{~m}^{3} / \mathrm{s}$

tegangan : $220 \mathrm{~V} / 380 \mathrm{~V}$

Frekuensi : $50 \mathrm{~Hz} / 60 \mathrm{~Hz}$

suhu $: \leq 50{ }^{\circ} \mathrm{C}$

Potensi debit aliran untuk sumber daya listrik dianalisis berdasarkan debit rata-rata sungai dan ketinggian jatuh air yang diperoleh pada titik pengamatan debit sungai sampai lokasi pembangunan pembangkit tenaga listrik

\section{HASIL DAN PEMBAHASAN}

Perencanaan Pembangkit Listrik Tenaga Mikrohidro (PLTMH) yang akan dibangun, untuk pengukuran debit sungai dilakukan pada 
setiap bulan selama setahun, parameter parameter pengukuran yang dilakukan adalah penentuan kecepatan air sungai, luas penampang basah dan kedalam air sungai masing-masing hasil pengukuran lapangan sebagai berikut:

A. Pengukuran kecepatan Air

Pengukuran dilakukan dikarenakan ingin mengetahui potensi kecepatan aliran sungai batanghari, pengukuran dilakukan dengan menggunakan water flow probe FP111, hasil pengukuran lapangan diperlihatkan pada tabel 1.data hasil pengukuran debit disungai batanghari dibawah.

\section{B. Pengukuran lebar penampang basah}

lebar penampang pada sungai batanghari diukur dari tepian sisi sungai sampai keseberang sisi sungai, batanghari dimana pengukuran dilakukan dengan menggunakan titik kordinat pada GPS.

\section{Pengukuran kedalaman air}

Pengukuran kedalaman air yang dilakukan adalah dengan menggunakan alat ukur Digital Sonar, dimana hasil pengukuran pada sungai dilakukan dengan membagi lebar saluran menjadi 12 segment dengan lebar sungai setiap bulannya \pm 450 meter (berdasarkan lebar penampang basar) maka setiap segment adalah $\pm 40 \mathrm{~m}$. Hasil pengukuran rata -rata kedalaman air diperlihatkan pada tabel 1. data hasil pengukuran debit di sungai batanghari.

Dari masing-masing komponen hasil pengukuran lapangan dalam perencanaan PLTMH debit air sungai dapat dihitung seperti diperlihatkan pada tabel 1. Data Hasil Pengukuran Debit Lapangan Di sungai Batanghari dibawah.

Tabel 1. Data hasil pengukuran debit Di sungai batanghari

\begin{tabular}{lcccc}
\hline Bulan & $\begin{array}{c}\text { Lebar } \\
\text { Penampang } \\
\text { Basah (m) }\end{array}$ & $\begin{array}{c}\text { Kedal } \\
\text { aman } \\
(\mathrm{m})\end{array}$ & $\begin{array}{c}\text { Kecepat } \\
\text { an Air } \\
(\mathrm{m} / \mathrm{s})\end{array}$ & $\begin{array}{c}\text { Debit } \\
\left(\mathrm{m}^{3} / \mathrm{s}\right)\end{array}$ \\
\hline Jan & 478 & 4,3 & 1 & 2055,4 \\
Feb & 485 & 5,5 & 0,9 & 2400,7 \\
Mar & 492 & 7,5 & 1 & 3690 \\
Apr & 523 & 6 & 1,1 & 3451,8 \\
Mei & 536 & 6,2 & 1,1 & 3655,5 \\
Jun & 540 & 4,4 & 1 & 2376
\end{tabular}

\begin{tabular}{lcccc} 
Jul & 462 & 3 & 1 & 1386 \\
Agus & 481 & 5,1 & 1 & 2453,1 \\
Sept & 478 & 3,2 & 0,7 & 1070,7 \\
Okt & 486 & 5,6 & 1,1 & 2721,6 \\
Nov & 495 & 4,6 & 0,9 & 2049,3 \\
Des & 509 & 4,6 & 0,9 & 2107,2 \\
\hline
\end{tabular}

Berdasarkan hasil data tabel 1 untuk nilai debit air di Sungai Batanghari bervariasi antara 1070,7 - $3690 \mathrm{~m}^{3} /$ detik dengan rata-rata $2.454,4 \mathrm{~m}^{3} /$ detik. terlihat bahwa fluktuasi debit air yang mengalir pada saluran sungai berbedabeda hal ini dilihat dari adanya perbedaan nilai debit maksimum maupun nilai debit minimum selama periode penelitian.

Untuk lebih jelasnya mengenai fluktuasi debit air selama penelitian tersaji pada gambar 3. Fluktuasi Debit Tiap Bulan berikut:

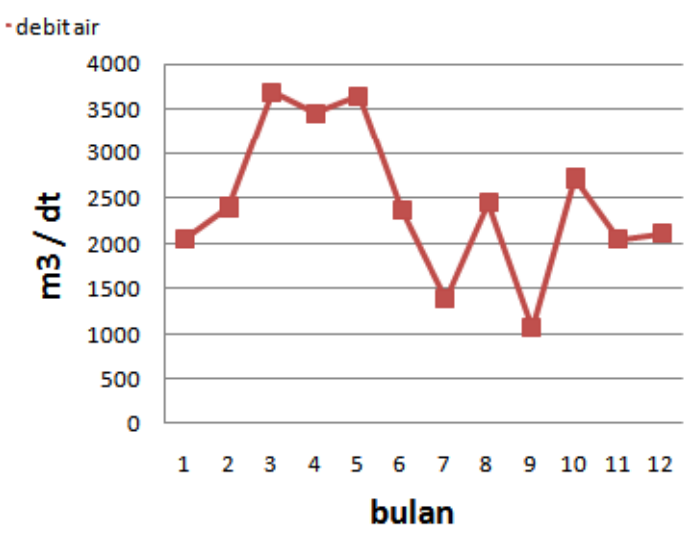

Gambar 3. Fluktuasi Debit Air Tiap Bulan

Untuk keperluan analisis Pembangkit Listrik Mikro Hidro (PLTMH), data tinggi jatuh air digunakan sebagai dasar perhitungan debit rencana serta kapasitas turbin yang digunakan pada pemasangan pembangkit dilokasi penelitian. 


\subsection{Perencanaan Pembangkit Listrik Mikro Hidro}

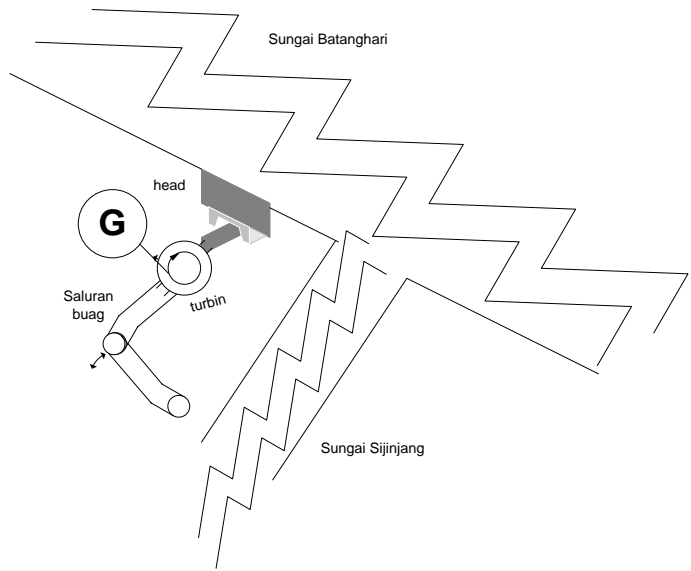

Gambar 4. Perencanaan PLTMH

A. Pemilihan Jenis Turbin dan Generator

Pemilihan Jenis Turbin dan Generator disesuiakan dengan kondisi lokasi di sungai batanghari, adapun generator set yang digunakan adalah model ZM-3, Parameter parameter dari Hidroelectric Generating Set ZM adalah sebagai berikut :

$\begin{array}{ll}\text { Output } & : 0,6 \mathrm{KW}-100 \mathrm{KW} \\ \text { head } & : 3-40 \mathrm{~m} \\ \text { Debit } & : 0,05 \mathrm{~m}^{3} / \mathrm{s}-2,0 \mathrm{~m}^{3} / \mathrm{s} \\ \text { tegangan } & : 220 \mathrm{~V} / 380 \mathrm{~V} \\ \text { Frekuensi } & : 50 \mathrm{~Hz} / 60 \mathrm{~Hz} \\ \text { suhu }: \leq 50{ }^{\circ} \mathrm{C}\end{array}$

\section{B. Tinggi Jatuh Air ( $\mathrm{m}$ )}

Untuk mendapatkan tinggi jatuh air dilakukan pengukuran dengan menggunakan metode water-filled tube dimana permukaan air pada sungai batanghari diukur sampai tempat turbin akan dipasang. Sehingga saluaran intake pada pembangunan Pembangkit Listrik Tenaga Mikro Hidro disungai batanghari didapatkan sebesar 3 meter berdasarkan kedalaman minimum rata - rata hasil pengamatan lapangan. Sedangkan pada desain letak posisi turbin disungai batanghari untuk mendapatkan tinggi jatuh air direncanakan 4 meter, seperti ditunjukan pada gambar 5. Disain Tinggi Jatuh Air dibawah.

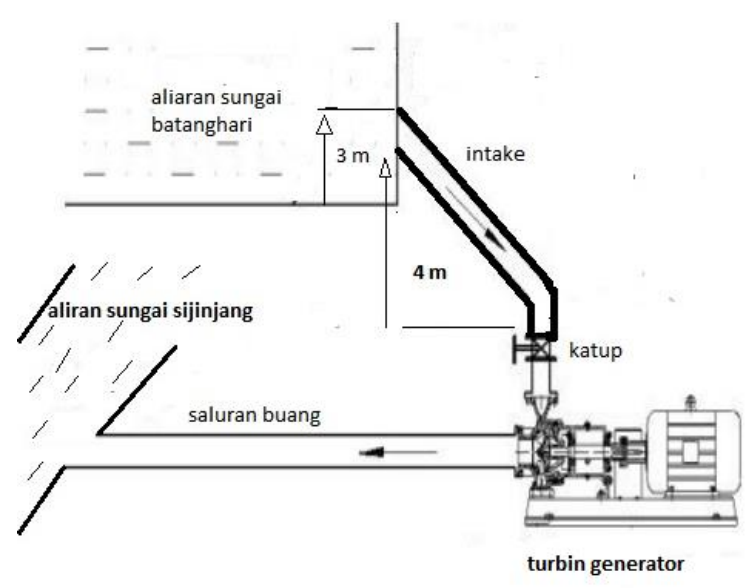

Gambar 5. Disain Tinggi Jatuh Air

\section{Desain Pipa Isap dan Power House}

Material pipa pengisap mempunyai dimensi panjang 10,0 meter dengan ketebalan 5, rumah pembangkit (power house) yang merupakan titik pusat pembangkitan direncanakan dengan ukuran 2,00 x 2,50 m. Pada rumah pembangkit ini ditempatkan :

- Turbin beserta pondasinya.

- Generator beserta fasiltasnya.

- Alat Kontrol beserta fasilitasnya.

- Ballast load besarta fasilitasnya.

\section{Desain Saluran Pembuang (Tail Race)}

Saluran pembuang (tail race) adalah salah satu bagian dari komponen PLTMH yang berfungsi untuk mengalirkan air yang berasal dari turbin ke saluran buang. saluran pembuang dialirkan ke sungai sijinjang dimana disain saluran tidak berbeda dengan desain saluran pembawa, namun yang membedakan adalah tidak adanya trashrack pada saluran pembuang.

Perencanna unit PLTMH dari hasil penelitian data lapangan dapat diasumsikan menggunakan rumus teoritis adapun hasil obtimasi dari perencanaan PLTMH teoritis didapat sebagai berikut :

$$
\begin{aligned}
& P=9,8 \cdot H \cdot Q \cdot \eta E \\
& P=9,8 \times 4 \mathrm{~m} \times 2 \mathrm{~m}^{3} / \mathrm{dt} \times 0,85 \\
& P=66,64 \mathrm{KW}
\end{aligned}
$$

dari hasil penelitian potensi sungai batanghari dapat dimanfaatkan sebagai energi listrik baru terbarukan tersebar dimana energi tersebut 
dapat digunakan kepada masyarakat pinggiran sungai sebagai unit produksi keramba ikan.

\section{SIMPULAN}

1. Analisis nilai kapasitas pembangkitan energi listrik di aliran sungai dengan menggunakan desain unit pembangkit, menunjukkan hasil yang lebih akurat dalam perancangan project PLTMH.

2. Potensi listrik PLTMH di Sungai batanghari Kecamatan jambi timur Kabupaten kota jambi, berdasarkan perencanaan desain pembangkit menunjukkan hasil sebesar 66,64 kilo watt.

\section{DAFTAR PUSTAKA}

[1] Sardi Salim,2017, Listrik Mikro Hidro Berdasarkan

Potensi Debit Andalan Sungai, Prosiding Seminar Nasional Teknik Elektro (FORTEI 2017) ISBN 978-602-6204-24-0.

[2] Macaringue D., 2009, The Potential for Micro-hidro Power Plants in Mozambique, Journal of Water Resources Planning and Management, Vol.128, 424-430.

[3]Arismunandar A., S. Kuwahara, 2000, Teknik Tenaga Listrik Jilid I: Pembangkitan dengan Tenaga Air, Pradnya Paramita, Jakarta

[4]Campbell J.R., 2010, Small Hydro and LowHead Hydro Power Technologies and Prospects, Congressional Research Service.

[5] Wilda Faradina, Hadi Suyono, ST., Mt., Ph.D., Ir. Teguh Utomo, MT., 2015, Kajian Kelayakan Ekonomis Pembangkit Listrik Tenaga Mikro Hidro Gunung Sawur 1 dan Gunung Sawur 2 Di Lumjang, Universitas Brawijaya

[4] Macaringue D., 2009, The Potential for Micro-hidro Power Plants in Mozambique, Journal of Water Resources Planning and Management, Vol.128, 424-430.

[5] Soemarto, C.D., 1999, Hidrologi Teknik, Edisi kedua, Erlangga, Surabaya 